\title{
Water vapour adsorption on water repellent sandy soils
}

\author{
Tomas Orfanus $^{1 *}$, Abdel-Monem Mohamed Amer ${ }^{2}$, Grzegorz Jozefaciuk $^{3}$, Emil Fulajtar ${ }^{4}$, \\ Anežka Čelková ${ }^{1}$ \\ ${ }^{1}$ Institute of Hydrology, Slovak Academy of Sciences, Dúbravská cesta 9, 84104 Bratislava, Slovakia. \\ ${ }^{2}$ Soil Science Department, Faculty of Agriculture, Menoufia University, Shebin El-Kom, Egypt. \\ ${ }^{3}$ Polish Academy of Sciences, Institute of Agrophysics, ul. Doswiadczalna 4, P.O. Box 201 20-290, Lublin, Poland. \\ ${ }^{4}$ Soil Science and Conservation Institute, Rožňavská 23, 83104 Bratislava, Slovakia. \\ *Corresponding author. E-mail: orfanus@uh.savba.sk
}

\begin{abstract}
Soil sorptivity is considered a key parameter describing early stages of water (rain) infiltration into a relatively dry soil and it is related to build-up complexity of the capillary system and soil wettability (contact angles of soil pore walls). During the last decade an increasing water repellency of sandy soils under pine forest and grassland vegetation has been frequently observed at Mlaky II location in SW Slovakia. The dry seasons result in uneven wetting of soil and up to hundredfold decrease in soil sorptivity in these vegetated soil as compared to reference sandy material, which was out of the reach of ambient vegetation and therefore readily wettable. As far as water binding to low moisture soils is governed by adsorption processes, we hypothesized that soil water repellency detected by water drop penetration test and by index of water repellency should also influence the water vapour adsorption parameters (monolayer water content, $W_{m}$, specific surface area, $A$, maximum adsorption water, $W_{a}$, maximum hygroscopic water $M_{H}$, fractal dimension, $D_{S}$ and adsorption energies, $E_{a}$ ) derived from BET model of adsorption isotherms. We found however, that the connection of these parameters to water repellency level is difficult to interpret; nevertheless the centres with higher adsorption energy prevailed evidently in wettable materials. The water repellent forest and grassland soils reached less than $80 \%$ of the adsorption energy measured on wettable reference material. To get more conclusive results, which would not be influenced by small but still present variability of field materials, commercially available homogeneous siliceous sand was artificially hydrophobized and studied in the same way, as were the field materials. This extremely water repellent material had two-times lower surface area, very low fractal dimension (close to 2) and substantially lower adsorption energy as compared to the same siliceous sand when not hydrophobized.
\end{abstract}

Keywords: Soil sorptivity; Hydrophobization; Adsorption isotherm; Fractal dimension; Specific surface area.

\section{INTRODUCTION}

Soil water repellency (SWR) has serious effects on natural ecosystems, like preferential flow, irregular pattern of vegetation growth, enhanced surface runoff and soil erosion (Burcar et al., 1994; DeBano, 1981; Ehwald et al., 1961; Imeson et al., 1992; Shakesby et al., 1993) and it is common especially in uncultivated sandy soils (Blanco-Canqui, 2011; Dekker, 1998) although different observations are also reported for instance from olive orchards (Bughici and Wallach, 2016) or from prairie soils (Eynard et al., 2004). Water repellency phenomenon results from the decrease in attraction between soil particles and water molecules which means that large-scale environmental effects may depend on processes that vary at microscopic scales. The hydraulic parameter, which appropriately describes the initial stage of infiltration, is sorptivity, $S$ and it has been shown in many studies that this parameter can be strongly influenced by water repellency (Orfanus et al., 2008; Orfanus et al., 2014; Tillman et al., 1989). Sorptivity lumps together the combined effects of various liquid water and vapour redistribution mechanisms occurring in relatively dry soils (Rose, 1968). Primarily, the sorptivity depends on pore size distribution of the infiltrated body, solid-liquid contact angle and liquid surface tension and viscosity. Contact angles result from the interactions between water and solid surfaces and the solid surface build-up. They govern the energy of water adsorption, $E_{a}$ (water-solid forces) and capillary condensation, $E_{c}$, which further modify parameters like surface area, $A$, as well as the fractal dimension, $D_{S}$ when estimated from the water vapour adsorption isotherm. Surface area relates to overall extent of wetted soil surface whereas the fractal dimension characterizes geometrical build-up complexity of the soil particles or aggregates (Avnir, 1989). The values of $D_{S}$ change from 2 (flat Euclidean plane) to 3 (highest possible surface roughness and complexity).

The aim of this study was to investigate whether the macroscopic water absorption process (here quantified by soil sorptivity parameter) within water repellent sandy soil is related to microscopic wetting processes (water vapour adsorption and capillary condensation) here quantified through specific soil surface area, fractal dimension and water vapour adsorption energy.

\section{MATERIALS AND METHODS Site description and soil analysis}

The experimental site Mlaky II near Sekule is located in the Borska nizina lowland (south-west Slovakia), $150 \mathrm{~m}$ above sea level. The average annual air temperature of this site is $9^{\circ} \mathrm{C}$ and the annual precipitation is $500-600 \mathrm{~mm}$. In this semiarid area $95 \%$ of precipitation is evaporated during the warm half-year. The soil is vegetated by different communities of plant species; grassland vegetation (consisting mostly of grass species of Poaceae family), 35-year-old Scots pine forest with patchy pattern of mosses and the bare-soil glade with patchy pattern of biological crust reported by Lichner et al. (2011). The sediment has combined fluvial and eolian origin in this area giving to evolve the Typic Ustipsamment soil (Soil Survey Division Staff, 2010) with sandy texture. This material formed mostly by silica sand (Table 1) extends to the groundwater table at a depth of about $2 \mathrm{~m}$. 
Table 1. Basic physical and chemical properties of studied soils as average values from indicated number of measurements.

\begin{tabular}{|ccccccccccc|}
\hline Locality & $\begin{array}{c}\text { Material } \\
\text { description }\end{array}$ & $\begin{array}{c}\text { Depth } \\
(\mathrm{mm})\end{array}$ & $\begin{array}{c}\text { Number of } \\
\text { measurements }\end{array}$ & $\begin{array}{c}\text { Sand } \\
(\%)\end{array}$ & $\begin{array}{c}\text { Silt } \\
(\%)\end{array}$ & $\begin{array}{c}\text { Clay } \\
(\%)\end{array}$ & $\begin{array}{c}\mathrm{CaCO}_{3} \\
(\%)\end{array}$ & $\begin{array}{c}\mathrm{C}_{\mathrm{org}} \\
(\%)\end{array}$ & $\begin{array}{c}\mathrm{pH}\left(\mathrm{H}_{2} \mathrm{O}\right) \\
(-)\end{array}$ & $\begin{array}{c}\mathrm{pH}(\mathrm{KCl}) \\
(-)\end{array}$ \\
\hline $\begin{array}{c}\text { Mlaky II } \\
\text { (Slovakia) }\end{array}$ & Forest soil & $0-50$ & 5 & 95.14 & 2.26 & 2.60 & $<0.05$ & 0.83 & 5.65 & 4.39 \\
\hline $\begin{array}{c}\text { Mlaky II } \\
\text { Slovakia) }\end{array}$ & $\begin{array}{c}\text { Grassland } \\
\text { soil }\end{array}$ & $0-50$ & 3 & 91.3 & 2.8 & 5.9 & $<0.05$ & 0.99 & 5.14 & 3.91 \\
\hline $\begin{array}{c}\text { Mlaky II } \\
\text { (Slovakia) }\end{array}$ & $\begin{array}{c}\text { Reference } \\
\text { material }\end{array}$ & $500-550$ & 3 & 94.9 & 1.7 & 3.4 & $<0.05$ & 0.03 & 5.54 & 4.20 \\
\hline
\end{tabular}

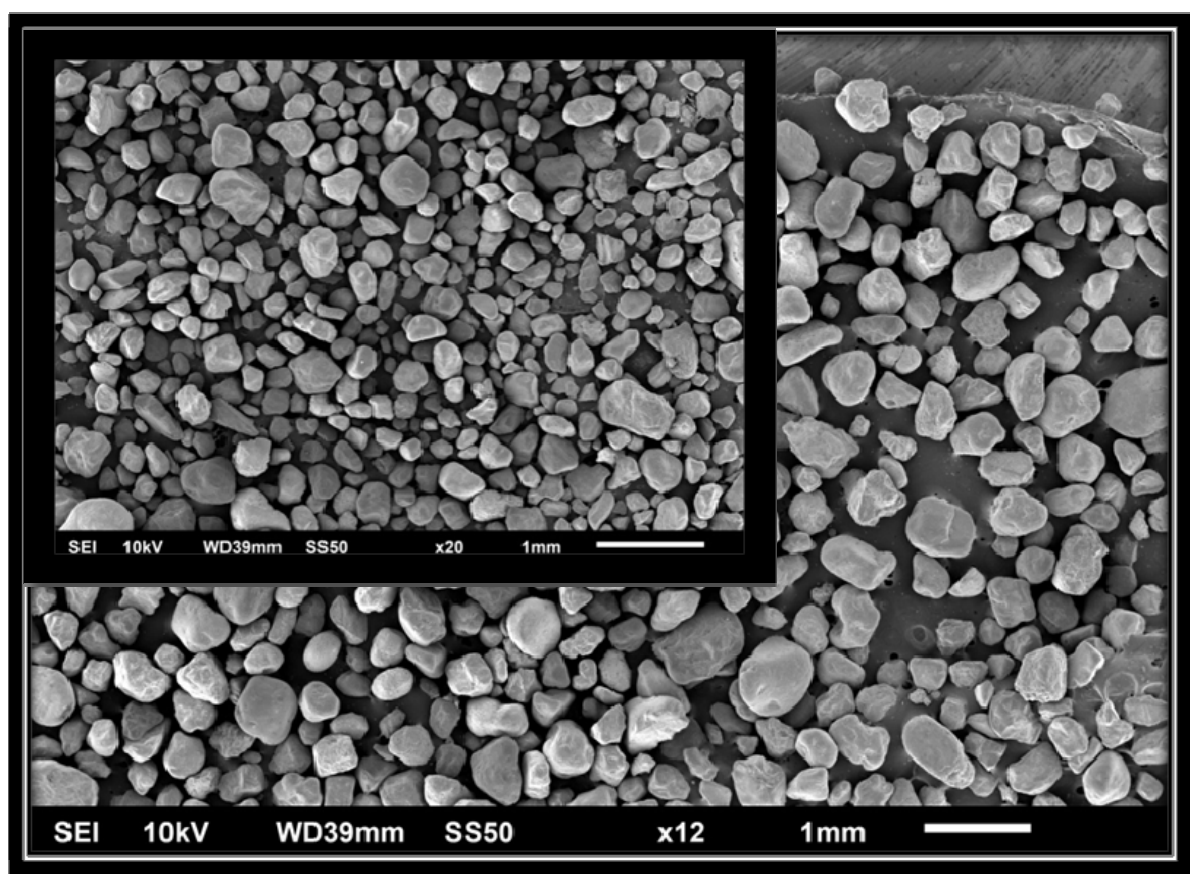

Fig. 1. The image of finer sandy particles of the building-sand material (smaller inside square-image) and coarser sandy particles of the reference material from Sekule (larger outside square-image) with same-size 1-millimetre scales.

The soil surface under grassland and pine-forest vegetation were analysed regarding their macroscopic and microscopic wetting characteristics, as described later. The fluvio-eolian deposit from a depth of $50 \mathrm{~cm}$ at the bare-soil glade site was taken as reference material, which was neither vegetated nor cultivated. Besides these three field materials, which are heterogeneous by nature, we prepared also homogeneous study material from commercially available quartz sand mined in nearby area of Zahorska lowland, which had slightly finer sand fraction (Fig. 1). Half of this material was artificially hydrophobized by composition of dodecylamin and propanol $(2 \mathrm{~g}$ of dodecylamine per litre of propanol). The resulting samples were absolutely repellent against water drop infiltration.

Standard methods (Fiala, 1999) were used for measurement of particle size distribution, (sedimentation method), $\mathrm{pH}\left(\mathrm{H}_{2} \mathrm{O}\right)$ and $\mathrm{pH}(1 \mathrm{M} \mathrm{KCl})$ at a soil/solution ratio $1: 2.5$, total organic carbon (oxidation with potassium dichromate and titration of non-reduced chromate), and carbonate content (volumetric analysis of the carbon dioxide released upon addition of $\mathrm{HCl}$ ). The field soil water content was measured with Theta Probe ML2x (Delta-T Devices).

\section{Water repellency and hygroscopicity measurements}

Water repellency measurements were performed in situ. Prior to the measurements the grass was cut out from the places being studied. Water drop penetration time (WDPT) test was always performed by placing five drops of distilled water from a medicinal dropper (drop volume: $58 \pm 5 \mu \mathrm{l}$ ) onto the soil surface around each infiltrometer installation in the field and measuring time of their disappearance (either imbibitions or evaporation).

Infiltration tests with water and/or 96.3\%-ethanol were performed in situ during three dry-spell field campaigns between 2006 and 2011 as described by Orfanus et al. (2014). A mini disk permeameter (Decagon Device with $45 \mathrm{~mm}$ diameter) under a small negative pressure head was applied. We decided to use $-20 \mathrm{~mm}$ pressure head to preserve consistency with previous or parallel measurements from the same location (e.g. Lichner et al., 2011). The total number of infiltration tests performed was: in the grassland soil 18 with water and 6 with ethanol, in the reference material 15 with water and 10 with ethanol, in the forest soil 18 with water and 6 with ethanol (Table 2). Sorptivities for water and ethanol, $S_{w}$ and $S_{e}$ respectively were estimated from the infiltration tests according to Zhang (1997) who proposed to estimate the sorptivity at suctions $h_{0} \leq 0$ from the first two terms of the Philip's infiltration equation (Philip, 1957):

$I=a\left(h_{0}\right) t^{1 / 2}+b\left(h_{0}\right) t$

where $I$ is the cumulative infiltration [L], $h_{0}$ is the applied suction [L], $t$ is the time [T], $a\left(h_{0}\right)$ and $b\left(h_{0}\right)$ are the parameters of the second-order polynomial approximating the $I$-record versus $t^{1 / 2}$. 
Table 2. Average values of hydrophysical characteristics of studied sandy materials.

\begin{tabular}{|c|c|c|c|c|c|c|c|c|c|c|}
\hline $\begin{array}{l}\text { Material } \\
\text { description }\end{array}$ & $\begin{array}{c}\text { SWC } \\
(\text { Vol-\%) }\end{array}$ & $\begin{array}{l}\text { WDPT } \\
\text { (s) }\end{array}$ & $\begin{array}{c}S_{w} \\
\left(\mathrm{~m} \mathrm{~s}^{-1 / 2}\right)\end{array}$ & $\begin{array}{c}S_{e} \\
\left(\mathrm{~m} \mathrm{~s}^{-1 / 2}\right)\end{array}$ & $\begin{array}{l}R I \\
(-)\end{array}$ & $\begin{array}{c}M_{H} \\
\text { (\% weight) }\end{array}$ & $\begin{array}{c}W_{a} \\
\text { (\% weight) }\end{array}$ & $\begin{array}{c}A \\
\left(\mathrm{~m}^{2} / \mathrm{g}\right)\end{array}$ & $\begin{array}{c}\left(E_{a}-E_{c}\right) / R T \\
(-)\end{array}$ & $\begin{array}{l}D_{S} \\
(-)\end{array}$ \\
\hline Forest soil & 1.3 & 4131 & $4.85 \times 10^{-5}$ & $3.16 \times 10^{-3}$ & 167.1 & 0.123 & 0.039 & 0.534 & 2.55 & 2.35 \\
\hline Grassland soil & 3.9 & 1996 & $2.33 \times 10^{-4}$ & $4.34 \times 10^{-3}$ & 36.30 & 0.207 & 0.068 & 0.988 & 2.62 & 2.57 \\
\hline Reference material & 7.2 & $<1$ & $4.90 \times 10^{-3}$ & $3.17 \times 10^{-3}$ & 1.26 & 0.076 & 0.040 & 0.954 & 3.24 & 2.34 \\
\hline Wettable sand & 0.13 & $<1$ & - & - & - & 0.185 & 0.090 & 2.25 & 3.07 & 2.31 \\
\hline $\begin{array}{l}\text { Hydrophobized } \\
\text { sand }\end{array}$ & 0.098 & $\begin{array}{l}\text { Extremely long } \\
\text { (until drops } \\
\text { evaporated) }\end{array}$ & 0 & 0 & - & 0.146 & 0.058 & 1.14 & 2.66 & 2.09 \\
\hline
\end{tabular}

WDPT = water drop penetration time; $S_{w}=$ sorptivity of water; $S_{e}=$ sorptivity of ethanol; $R I=$ index of water repellency; $(-20 \mathrm{~mm})=$ under a negative tension $h_{0}=-20 \mathrm{~mm} ; A$ is the specific surface area; $D_{S}$ is surface fractal dimension; $W_{a}$ is the maximum adsorption water; and $M_{H}$ is the maximum hygroscopic water.

The sorptivity $S\left(h_{0}\right)\left[\mathrm{LT}^{-1 / 2}\right]$ related to suction $h_{0}$ can be understood as:

$S\left(h_{0}\right)=a\left(h_{0}\right)$

An index of water repellency, $R I[-]$, was evaluated as suggested by Tillman et al. (1989):

$R I=1.95\left(S_{\mathrm{e}}\left(h_{0}\right) / S_{\mathrm{w}}\left(h_{0}\right)\right)$

The value of 1.95 accounts for differences in surface tension and viscosity of ethanol and water (Hallett and Young, 1999). Ethanol readily infiltrates into hydrophobic soils and its contact angle is frequently assumed to be zero. $S_{e}\left(h_{0}\right)$ provides a measure of liquid transport in soil that is not influenced by repellency and so it depends only on pore structure. Tillman et al. (1989) defined soils with $1<R I<1.95$ as non-water repellent, and reported a value of $R I=19$ in a field of subcritically water repellent soil. Moderately repellent soils tend to have $R I$ between 20 and 40, and severely repellent soils have been found to have $R I$ up to 80 (Clothier et al., 2000), or even 360 (Lichner et al., 2007).

\section{Estimating water adsorption parameters}

Values of $E_{\mathrm{a}}, A$ and $D_{S}$ can easily be estimated using a water vapour adsorption isotherm (Cary et al. 1964; Verhoef et al., 2006) which is a function relating the amount of water present in the soil to relative water vapour pressure $\left(P / P_{0}\right)$.

The water vapour adsorption isotherms were determined gravimetrically at $20^{\circ} \mathrm{C}$. Four 5-7 g oven-dried soil samples taken from each studied material were placed in weighing vessels and closed in a desiccator at $20^{\circ} \mathrm{C}$. Stepwise increasing values of $P / P_{0}$ in a desiccator $(P$ is the actual water vapour pressure and $P_{0}$ is saturated vapour pressure at the temperature of the measurements) were applied by using saturated salt solutions of $\mathrm{LiCl}_{2}, \mathrm{CaCl}_{2}, \mathrm{~K}_{2} \mathrm{CO}_{3}, \mathrm{NH}_{4} \mathrm{NO}_{3}, \mathrm{KCl}$ and $\mathrm{K}_{2} \mathrm{SO}_{4}$ having $P / P_{0}$ values of $0.10,0.32,0.45,0.65,0.85$ and 0.98 , respectively. The sample moisture contents $W[\%]$ were measured after weight equilibration for each particular solution had been established.

From the experimental vapour adsorption data the following parameters were calculated applying the BET model of adsorption isotherm (Brunauer et al., 1938):

1) critical limit between adsorbed and wetting films $\left(W_{a}\right)$ equal to adsorption at $P / P_{0}=0.65$ (Amer, 2003).

2) maximum hygroscopic water $\left(M_{H}\right)$ equal to adsorption at $98 \%$ humidity.

3) surface area and adsorption energy using the linear plots of the standard BET equation in $P / P_{0}$ range of $0-0.4$ :
$1 / W\left[\left(P_{0} / P\right)-1\right]=P / P_{0}(C-1) / W_{m} C+1 / W_{m} C$

where $W_{m}[-]$ is the moisture content in a monolayer (when the soil surface is completely covered by a single-molecular layer of water), and $C$ is a constant. Although the BET model is a standard technique to estimate the monolayer moisture content, it should be mentioned that adsorbates chemically reactive with material surfaces, like is the water vapour for instance, may not preferably adsorb as an ideal monolayer and the $\mathrm{Wm}$ values could be biased in soils with high cation exchange capacity (Newman, 1983).

From the intercept on the $\mathrm{y}$-axis equal to $1 / W_{m} C$ and the slope equal to $(C-1) / W_{m} C$, both $W_{m}$ and $C$ were determined and the total specific surface area was calculated as:

$A\left[\mathrm{~m}^{2} / \mathrm{g}\right]=36.16 W_{m}$

and the adsorption energy $E_{a}\left[\mathrm{~J} \cdot \mathrm{mol}^{-1}\right]$ as:

$E_{a}=E_{c}+R T \ln C$

where $R=8.314 \mathrm{~J} \cdot \mathrm{mol}^{-1} \cdot \mathrm{K}^{-1}$ is the universal gas constant and $E_{c}\left[\mathrm{~J} \cdot \mathrm{mol}^{-1}\right]$ is the condensation energy of adsorbate.

4) surface fractal dimension $D_{S}[-]$ from a slope $-1 / \mathrm{m}$ of a linear part (if any) of the equation (Jarzebski et al., 1997) applied for higher $P / P_{0}$ values (in capillary condensation regime):

$\ln W=-1 / \mathrm{m} \ln \left[-\ln \left(P / P_{0}\right)\right]+$ const

The magnitude of $1 / \mathrm{m}$ gives two possible adsorption regimes. For $1 / \mathrm{m}<1 / 3$, the adsorption occurs within van der Waals regime and the surface fractal dimension is:

$D_{S}=3\left(1-\frac{1}{m}\right)$

and for $1 / \mathrm{m}>1 / 3$ the adsorption is governed by the capillary condensation mechanism and:

$D_{S}=3-\frac{1}{m}$

\section{RESULTS AND DISCUSSION}

The basic physical and chemical characteristics of the studied soil materials are presented in Table 1. All field materials have sandy texture, similar $\mathrm{pH}$, and low carbonate content but vary in organic matter content. The reference material, which 
comes from the deeper layer $(500-550 \mathrm{~mm})$ of the bare soil, contains almost zero organic carbon. The building-sand material was finer in size distribution of sandy particles (Fig. 1) but contained no clay particles and no organic carbon, as well. In contrast to field materials, it also contained certain amount of iron oxide coatings as proved by the chemical analysis of 6molar $\mathrm{HCl}(6 \mathrm{~mol} / \mathrm{l})$ extract.

\section{Water repellency effects at scale of minidisc infiltrometer measurements}

Mean WDPT values measured under field conditions during the dry seasons are listed in Table 2. WDPT is decreasing in the sequence forest soil $>$ grassland soil $»$ reference material. It has been very frequently reported in literature over the last years that coniferous forest litter causes the strongest levels of SWR (e.g. de Blas et al., 2013; Flores-Mangual et al., 2013; Lozano et al., 2013), most probably due to high content of hydrophobic resins, terpens, and waxes.

Distinct differences in infiltration rates (measured by minidisc tension infiltrometer) were observed between the reference material and the forest and grassland soils. This had manifested in variable sorptivity for water differing by orders among these three field materials (Table 2). The average values of the sorptivity for water for particular field materials were $4.85 \times 10^{-5} \mathrm{~m} . \mathrm{s}^{-1 / 2}$ in forest soil, $2.33 \times 10^{-4} \mathrm{~m} . \mathrm{s}^{-1 / 2}$ in grassland soil and $4.9 \times 10^{-3} \mathrm{~m} \cdot \mathrm{s}^{-1 / 2}$ in reference material, and the standard deviations of the sorptivity for water were $1.62 \times 10^{-4} \mathrm{~m} \cdot \mathrm{s}^{-1 / 2}$, $1.56 \times 10^{-4} \mathrm{~m} . \mathrm{s}^{-1 / 2}$ and $6.33 \times 10^{-3} \mathrm{~m} . \mathrm{s}^{-1 / 2}$, respectively. Orfanus et al. (2014) reported how infiltration advances only through a (wettable) part of the soil surface under the infiltrometer disk in the water repellent forest and grassland soils at the same location. Even after the measurement was repeated several times exactly at the same place, the pattern of wetted surface exhibited certain temporal stability in both water repellent soils. From this reason we suggest that sorptivity estimated in strongly water repellent soils should be understood as effective value strictly relevant for the applied scale of measurement. $S_{w}$ variability (expressed as standard deviation) is 40-times higher in the reference material in relation to water repellent soils, while the relative variability (expressed as coefficient of variability, CV) is highest in the forest soil. Coefficient of variability equalled $67 \%$ in grassland soil, $334 \%$ in forest soil and $129 \%$ in the reference material.
Sorptivities for ethanol and water differed by one to two orders of magnitude in grassland and forest soils while they were similar in the reference sandy material (Table 2). The indices of water repellency $(R I)$ calculated from ethanol and water sorptivities according to Eq. 3 for particular soil materials are listed in Table 2 as well. It should be mentioned that $R I$ indices are slightly underestimated by this method because applying the same suction for both, water and ethanol does not ensure the same imposed volumetric liquid content on the supply surface. Anyway, $R I$ index has revealed that the forest soil and the grassland soil respectively were severely or moderately water repellent, while the reference material should be considered wettable.

\section{Water repellency effect on vapour adsorption and capillary condensation processes in field soils}

As the capillary absorption of water (characterized by sorptivity parameter) described in previous chapters was strongly reduced by hydrophobic behaviour in both, forest and grassland soils, the question arises whether not only the capillary absorption but also the vapour adsorption and capillary condensation processes are (and to what extent) affected by soil water repellency. Water repellency is caused by low solid-surface free energy of the soil particles, which results in a weak attraction between the solid and liquid phases (Goebel et al., 2007; Roy and McGill, 2002). Since Miyamoto et al. (1972) published their pioneer work on water vapour adsorption in water repellent soils, only very few other works followed this topic (e.g. Fernández-Gálvez and Mingorance, 2010; Ojeda et al., 2010), which however have not progressed in answering the aboveformulated question. Miyamoto et al. (1972) did not find any effect of water repellency related to the amount of adsorbed water, the shape of the adsorption isotherm or the integral free energy of adsorption on variably-textured soils, having different SWR levels from locations which were far apart. They suggested that the mechanism of SWR were occurring either at the portion which is beyond the vapour adsorption range, or that other soil properties which were variable among the samples mask the effect. An interesting experiment was conducted by Hurrass (2006) who compared the rate of wetting of wettable and water repellent organo-mineral soils by water vapour and separately by liquid water, finding that wetting of water repellent soil was retarded only when wetted by liquid phase. She observed that wetting by vapour phase (at $99 \%$ relative humidity)

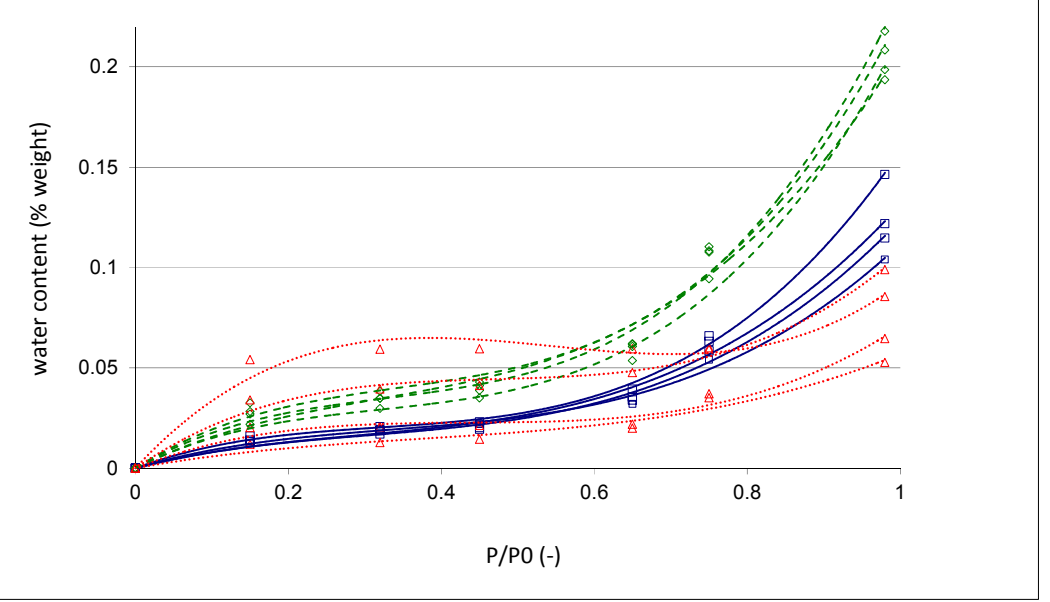

Fig. 2. Water vapour adsorption isotherms measured for water repellent forest soil (squares), water repellent grassland soil (circles) and wettable reference material (triangles). 


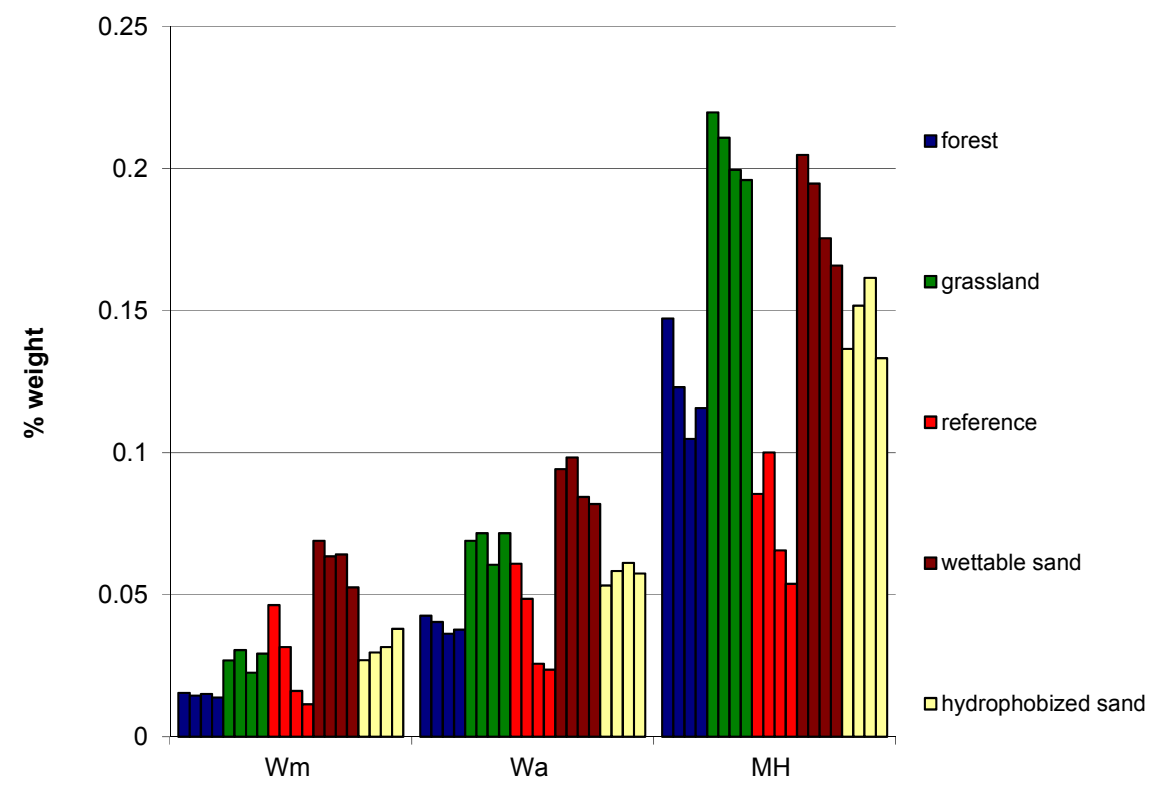

Fig. 3. The physico-chemical characteristics of studied soils. Wm is the unimolecular layer water content (when multiplied by 36.16 we get the specific surface area, $S S A$ parameter in $\mathrm{m}^{2} / \mathrm{g}$ ), $W_{a}$ is the maximum adsorption water, and $M_{H}$ is the maximum hygroscopic water.

was equally fast in both wettable and water repellent samples. Author explained that during the experiment with vapour phase only the mineral fraction underwent wetting while the organics remained completely dry.

The adsorption isotherms measured on our materials exhibited typical sigmoidal shape (Fig. 2) that suggests occurrence of adsorption in multi-molecular layers rather than a monomolecular one (Amer, 2009). Figure 3 shows the main physicochemical characteristics estimated from the vapour adsorption isotherms by BET model. It is obvious that all of them are highest in the grassland soil in case of field materials (see also average values in Table 2), while most variable they are again in the reference material.

The forest soil with the highest SWR level had the lowest surface area despite the high organic matter content which normally makes the soil particle built-up more complex. This could be a consequence of low clay content (Table 1) but also supports the hypothesis of Hurrass (2006) that the water vapour is hardly adsorbed on hydrophobic organic surfaces. The highest surface area of the grassland soil which was also strongly water repellent but had the highest clay content would prefer the first hypothesis. Moreover the fractal dimension, which characterizes the complexity of surface and porous structure was again highest in grassland soil (although comparable with reference material) which also points to the high relative influence of clay content on vapour adsorption process.

The rate of molecular adsorption at the maximum hygroscopic water content $\left(W_{m} / M_{H}\right)$ and scaled adsorption energies calculated according to Eq. 6 (see in Table 2) indicate that the adsorption centres' distribution was shifted to those with higher energy in the reference material compared to both water repellent soils. The average $W_{m} / M_{H} * 100$ equals $12.2 \%, 13.2 \%$ and $32.9 \%$ in forest soil, grassland soil and reference material respectively and their respective adsorption energies were 2.55, 2.62 and 3.24. The magnitude of $1 / \mathrm{m}$ in Eq. 8 indicates that within the reference material the van der Waals regime of molecular adsorption prevails, while in the forest and grassland soil the adsorption is predominantly governed by capillary condensation process at higher relative vapour pressures. It clearly points to the stronger water-solid interactions in reference material.

\section{Water repellency effect on vapour adsorption and capillary condensation processes in commercial build-send material}

To support the interpretation of our results with field materials we compared them with samples from the commercially available building material, half of which were artificially hydrophobized. The resulting samples were absolutely water repellent. No infiltration of water was observed in this material (called hydrophobized sand in Table 2 and Fig. 2) for hours. The WDPT approached the time necessary for water drop evaporation. The adsorption isotherm analysis showed that surface of hydrophobized building sand material is very smooth. The fractal dimension was close to 2 (Table 2). The surface area of the original (not hydrophobized) building sand material was the highest among all studied materials, while it was reduced twice when hydrophobized. This building sandy material contains finer sand fraction than the reference field material (Fig. 1) and moreover the presence of iron oxide coatings was detected there. These two factors could be responsible for the highest specific surface among all studied materials. It is not clear yet, whether this reduction of $A$ after hydrophobization was caused by prevention of adsorption of water molecules in a part of the particles' surfaces or the hydrophobizing agent filled some part of the porous system and smoothed the roughness of particle surfaces, as indicated by very low $D_{S}$. The sand particles in building-sand material were approximately 4-times smaller in diameter than they were in the reference material. This fact, together with the detection of iron oxide coatings proved by $\mathrm{HCl}$ extraction could provide the possible explanation of the largest specific surface area of the building sand material estimated from the vapor adsorption isotherms. The maximum hygroscopic water amount was similar in both sands, slightly lower in the hydrophobized one, but the maximum adsorption water, e.g. water adsorbed in multimolecular layers, was reduced by approximately $35 \%$ in hydrophobized sand. The ratio of molecular adsorption in the maxi- 
mum hygroscopic water content $\left(W_{m} / M_{H} * 100\right)$ was $33.6 \%$ and $21.8 \%$ in wettable and hydrophobized building sand samples respectively and their respective adsorption energies were 3.07 and 2.66. It means that all parameters (estimated from the vapour adsorption isotherms), which are relevant to support or challenge the hypothesis about the effect of water repellency on processes at scales of vapour adsorption and capillary condensation fully supported it for the case of artificial hydrophobization of originally wettable sandy material (Fig. 3).

\section{CONCLUSIONS}

The wetting properties of wettable and water repellent sandy materials were studied in the light of capillary absorption of water, characterized by sorptivity parameter and water vapour adsorption and capillary condensation processes characterized by specific soil surface area, fractal dimension and water vapour adsorption energy. The latter two wetting processes were evaluated by application of BET model on the measured water vapour adsorption isotherms. We conclude that:

1. Capillary absorption process was strongly influenced by SWR (quantified by WDPT test and repellency index) in case of the field sandy soils in Sekule. The wettable reference material had by 1 to 2 orders higher sorptivity during the dry seasons when compared to water repellent grassland and forest soils, respectively.

2. In case of wettable reference material and water repellent forest and grassland sandy soils from Sekule there was no explicit relationship between SWR and hydrophysical characteristics like specific surface area $(A)$, maximum adsorbed water $\left(W_{a}\right)$, and maximum hygroscopic water $\left(M_{H}\right)$, which characterize the wetting of soil at the process scale of vapour adsorption and capillary condensation. However, significantly lower adsorption energy, $E_{a}$, which is the characteristics of the force of adsorption independent on $A$, was estimated for both water repellent soils when compared to reference material.

3. More explicit relationships were apparent in case of artificially hydrophobized sand samples prepared from the commercial building sand, where significant reduction of $A$, $W_{a}$, and $M_{H}$ was observed when compared to untreated (readily wettable) samples.

Highest adsorption energies and $W_{m} / M_{H}$ ratios indicate that in studied wettable materials there are proportionally more adsorption centres with higher free surface energy when compared to water repellent materials. A more detailed analysis of the surface adsorption energy distribution in these materials will be the main subject of our follow-up research.

Acknowledgement. This study was supported by the projects VEGA $2 / 0167 / 12$ and 2/0152/15, and partially by the Research and Development Operational Programme, the project Excellence Centre of Integral Territory Flood Protection, code ITMS 26240120004, funded by the ERDF.

\section{REFERENCES}

Amer, A.M., 2003. Soil Hydro-Physics. First Part, Al-Dar Alarabia Publishing Foundation, Cairo, Egypt, ISBN 977258-179-5.

Amer, A.M., 2009. Moisture adsorption capacity and surface area as deduced from vapour pressure isotherms in relation to hygroscopic water of soils. Biologia, 64, 3, 516-521.

Avnir, D., 1989. The Fractal Approach to Heterogeneous Chemistry: Surfaces, Colloids, Polymers. Wiley, Chichester, UK.
Blanco-Canqui, H., 2011. Does no-till farming induce water repellency to soils? Soil Use Manag., 27, 2-9.

Brunauer, S., Emmett, P.H., Teller, E., 1938. Adsorption of gases in multi-molecular layers. J. Am. Chem. Soc., 60, 309-319.

Bughici, T., Wallach, R., 2016. Formation of soil-water repellency in olive orchards and its influence on infiltration pattern. Geoderma, 262, 1-11.

Burcar, S., Miller, W., Tyler, S., Johnson, D., 1994. Seasonal preferential flow in two Sierra Nevada soils under forested and grassland cover. Soil Sci. Soc. Am. J., 58, 1555-1561.

Cary, J.W., Kohl, R.A., Taylor, S.A., 1964. Water adsorption by dry soil and its thermodynamic functions. Soil Sci. Soc. Amer. Proc., 28, 309-313.

Clothier, B.E., Vogeler, I., Magesan, G.N., 2000. The breakdown of water repellency and solute transport through a hydrophobic soil. J. Hydrol., 231-232, 255-264.

DeBano, L.F., 1981. Water repellent soils: a state-of-the-art. Pacific Southwest Forest and Range Experiment Station P.O. Box 245, Berkeley, California 94701, 25 p.

de Blas, E., Almendros, G., Sanz, J., 2013. Molecular characterization of lipid fractions from extremely waterrepellent pine and eucalyptus forest soils. Geoderma, 206, 75-84.

Dekker, L.W., 1998. Moisture variability resulting from water repellency in Dutch soils. Doctoral thesis. Wageningen Agricultural University, The Netherlands, $240 \mathrm{p}$.

Ehwald, E., Vetterlein, E., Buchholz, F., 1961. Das Eindringen von Niederschlägen und Wasserbewegungen in sandigen Waldböden. Z. Pflanzenernaehr. Dueng. Bodenkd., 93, 202209.

Eynard, A., Schumacher, T.E., Lindstrom, M.J., Malo, D.D., Kohl, R.A., 2004. Wettability of soil aggregates from cultivated and uncultivated Ustolls and Usterts. Aust. J. Soil Res., 42, 163-170.

Fernández-Gálvez, J., Mingorance, M.D., 2010. Vapour and liquid hydrophobic characteristics induced by presence of surfactants in an agricultural soil. Geoderma, 154, 321-327.

Fiala, K., 1999. Standard methods of soil analyses. Soil Fert. Res. Inst., Bratislava, Slovakia. (In Slovak.)

Flores-Mangual, M.L., Lowery, B., Bockheim, J.G., Pagliari, P.H., Scharenbroch, B., 2013. Hydrophobicity of Sparta sand under different vegetation types in the Lower Wisconsin River Valley. Soil Sci. Soc. Am. J., 77, 1506-1516.

Goebel, M.O., Woche, S.K., Bachmann, J., Lamparter, A., Fischer, W.R., 2007. Significance of wettability-induced changes in microscopic water distribution for soil organic matter decomposition. Soil Sci. Soc. Am. J., 71, 1593-1599.

Hurrass, J., 2006. Interactions between soil organic matter and water with special respect to the glass transition behaviour. Dissertation Thesis. TU Berlin, $125 \mathrm{p}$.

Imeson, A.C., Verstraten, J.M., van Mulligen, E.J., Sevink, J., 1992. The effects of fire and water repellency on infiltration and runoff under Mediterranean type forests. Catena, 19, $345-361$.

Jarzebski, A.B., Lorenc, J., Pajak, L., 1997. Surface fractal characteristics of silica aerogels. Langmuir, 13, 1031-1035. http://dx.doi.org/10.1021/la960011z

Lichner, L., Hallett, P.D., Feeney, D., Ďugová, O., Šír, M., Tesař, M., 2007. Field measurement of soil water repellency and its impact on water flow under different vegetation. Biologia, 62, 537-541.

Lichner, L., Eldridge, D.J., Schacht, K., Zhukova, N., Holko, L., Sir, M., Pecho, J., 2011. Grass cover influences hydro- 
physical parameters and heterogeneity of water flow in a sandy soil. Pedosphere, 21, 719-729.

Lozano, E., Jiménez-Pinilla, P., Mataix-Solera, J., Arcenegui, V., Bárcenas, G.M, González-Pérez, J.A., García-Orenes, F., Torres, M.P., Mataix-Beneyto, J., 2013. Biological and chemical factors controlling the patchy distribution of soil water repellency among plant species in a Mediterranean semiarid forest. Geoderma, 207-208, 212-220.

Miyamoto, S., Letey, J., Osborn, J., 1972. Water vapor adsorption by water-repellent soils at equilibrium. Soil Sci., 114, $180-184$

Newman, A.C.D., 1983. The specific surface area of soils determined by water sorption. J. Soil Science, 34, $23-32$.

Ojeda, G., Mattana, S., Alcañiz, J.M., Marando, G., Bonmatí, M., Woche, S.K., Bachmann, J., 2010. Wetting process and soil water retention of a mine soil amended with composted and thermally dried sludges. Geoderma, 156, 399-409.

Orfanus, T., Bedrna, Z., Lichner, L., Hallett, P.D., Kňava, K., Sebiň, M., 2008. Spatial variability of water repellency in pine forest soil. Soil Water Res., 3, 123-129.

Orfanus, T., Dlapa, P., Fodor, N., Rajkai, K., Sándor, R., Nováková, K., 2014. How severe and subcritical water repellency determines the seasonal infiltration in natural and cultivated sandy soils. Soil \& Tillage Research, 135, 49-59.

Philip, J.R., 1957. The theory of infiltration: 1 . The infiltration equation and its solution. Soil Sci., 83, 345-357.
Rose, D.A., 1968. Water movement in dry soils. I. Physical factors affecting sorption of water by dry soil. J. Soil Sci., 19, 81-93.

Roy, J.L., McGill, W.B., 2002. Assessing soil water repellency using the molarity of ethanol droplet (MED) test. Soil Sci., 167, 83-97.

Shakesby, R.A., Coelho, C.O.A., Ferreira, A.D., Terry, J.P., Walsh, R.P.D., 1993. Wildfire impacts on soil erosion and hydrology in wet Mediterranean forest, Portugal. Int. J. Wildland Fire, 3, 95-110.

Soil Survey Division Staff, 2010. Soil Survey Manual. Soil Conservation Service. U.S. Department of Agriculture Handbook 18, Washington DC.

Tillman, R.W., Scotter, D.R., Wallis, M.G., Clothier, B.E., 1989. Water-repellency and its measurement by using intrinsic sorptivity. Aust. J. Soil Res., 27, 637-644.

Verhoef, A., Diaz-Espejo, A., Knight, J.R., Villagarcía, L., Fernández, J.E., 2006. Adsorption of water vapor by bare soil in an olive grove in Southern Spain. J. Hydrometeor., 5, 1011-1027.

Zhang, R., 1997. Determination of soil sorptivity and hydraulic conductivity from the disk infiltrometer. Soil Sci. Soc. Am. J., 61, 1024-1030.

Received 7 October 2016 Accepted 16 May 2017 